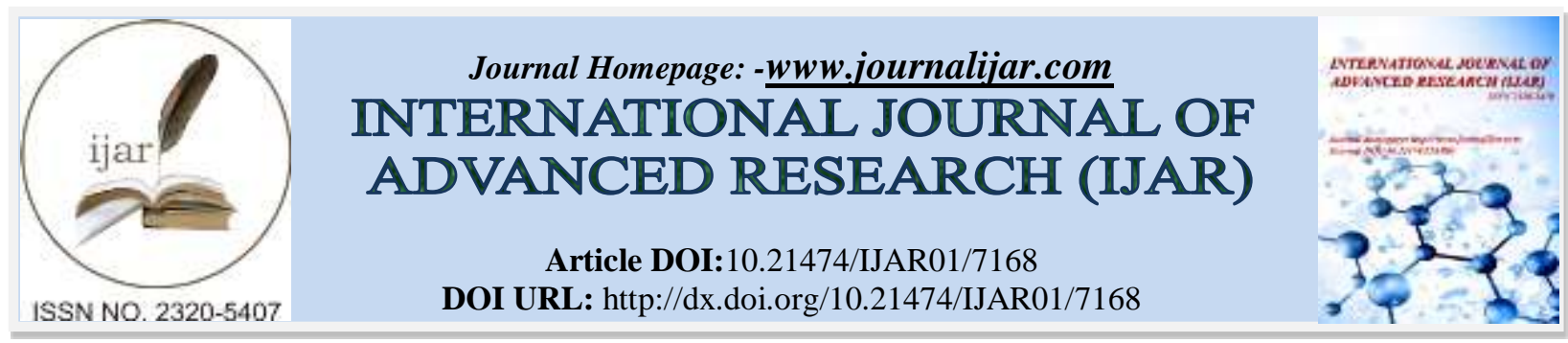

RESEARCH ARTICLE

\title{
THE EFFECTIVENESS of the MODULE-BASED STEM (SCIENCE, TECHNOLOGY, ENGINEERING, MATHEMATICS) to STUDY PHYSICS AT VOCATIONAL HIGH SCHOOL.
}

Ervina Febriyanti, Indrawati, Supeno, Sutarto and I Ketut Mahardika.

Department of Post Graduate Science Education, Jember University, East Java, Indonesia.

\section{Manuscript Info}

Manuscript History

Received: 22 March 2018

Final Accepted: 24 April 2018

Published: May 2018

Keywords:-

The effectiveness of Module, Based

STEM (Science, Technology,

Engineering, and Mathematics).

\section{Abstract}

The purpose of this research is to know the effectiveness of the Module-based STEM (Science, Technology, Engineering, and Mathematics) to study physics at Vocational High School. This research was conducted at SMK PGRI 1 Banyuwangi, Banyuwangi, in April 2018 processed X TKR 3 of 29 students in the even Semester year 2017/2018 lessons. The research design used was one group pretest-posttest design. Based on the results of the effectiveness test, then it is known that the $\mathrm{N}$-value gain of 0.63 . Based on the research that has been done, it can be concluded that the module-based STEM has been effective in increasing student learning results before using a module-based STEM after using module STEM.

Copy Right, IJAR, 2018,. All rights reserved.

\section{Introduction:-}

STEM (Science, Technology, Engineering, and Mathematics) is an important issue in education today (Becker \& Park, 2011). The term STEM was introduced by NSF (National Science Foundation) the United States in 1990 's as an abbreviation for "Science, Technology, Engineering, Mathematics \&" (Sanders, 2009:20). So in the context of Indonesia, STEM refers to the four areas of science, namely science, technology, engineering, and mathematics. Learning is the integration of learning STEM science, technology, engineering, and math are recommended to help the success of 21st-century skills (Beers, 2011). Characters in STEM Learning directly is the ability of learners to recognize a concept or knowledge in a case (Bybee, 2010:46) as in physics, STEM learning helps learners to use the tech and arranging a trial could prove a legal or scientific concept. The purpose of education STEM is producing students who later on when they plunged in the community, they are able to develop the competencies that have been perceived to be applied in a variety of situations and the problems they face every day (Mayasari et al, 2014). In the domain of mathematics, the impact on learning with the help of different types of embedded knowledge in the field of obtaining promising technology and engineering (Honey, Pearson, \& Schweingrube, 2014:3).

Through the approach of STEM students don't just recite the concept, but rather to how students know and understand science concepts and terms in everyday life. White (2010) States that approach the STEM in the introduction that will provide learning for learners through post-secondary school. The STEM is usually followed by an active learning project-based and problem-solving abilities can reach and assist learners in acquiring learning experiences are pleasant (Verma, Dickerson, \& McKinney, 2011:30). This can encourage a spirit of students in learning. While according to Hanover Research (2011) about Project-based Learning and Best Practices for Delivering High School STEM Education, STEM approach to Problem Based Learning learning supported by 
inquiry-based learning experiences encourage learners to answer questions that challenge and are working to solve the problem are complex.

In addition, the use of the right materials becomes an important means in STEM learning. In STEM learning skills and knowledge used simultaneously by the learners (Pfeifer, Ignatov, \& Poelmans, 2013:49). Learning materials were instrumental in ensuring the effectiveness of learning activities, one of which is a module (Department of national education, 2008).

The effectiveness of the methods of learning is a measure that relates to the success rate of a learning process. Whereas the effectiveness of the learning process according to Sudjana (1990:50) berakitan by the way, the efforts, techniques, and strategies used to achieve the goal. While the development instrument, keefektivan module, the theory in the world of education, Van den Akker (1999:10) States that "Effectiveness refers to the extents that the experiences and outcomes with the intervention are consistent with the intended aims" i.e. keefektivan refers to the levels that the experience and the results of interventions are consistent with the intended purpose. A business is said to be effective when the business reaches its destination.

The module is a book written with the goal of keeping learners can learn independently without or with the guidance of a teacher (Majid, 2007:176). While according to Suprawoto (2009:2) learning modules are a means of instruction in writing or print, arranged systematically, learning material, method of loading, basic competence-based learning objectives or indicators achievement of competence, independent learning activity instructions (self instructional), and gives the opportunity to students to test yourself via exercise presented in the module.

The material presented in the module this is the STEM material fluid static hydrostatic pressure material that includes, Pascal's law, and the law of Archimedes. The selection of this material because there are many applications in everyday life with regard to such material. This static fluid material can be taught using STEM science, i.e., the approach in finding the concept, the technology can be taught by explaining the various application of technology associated with the material, through engineering students can be taught making or designing simple tools with regard to the material and the math used to formulate mathematical equations associated the concept of material as well as in the calculation.

Based on preliminary research conducted against teachers and students aware that $80 \%$ of the teachers stated has been using the module's learning or learning materials that are not yet present contextual materials-related science, technology, and mathematics implies an increase in student learning outcomes before and after using the module. Therefore need to do research to find out the effectiveness of STEM learning in Modules.

\section{Research Methods:-}

The research design used was one group pretest-posttest design i.e. the design research with the use of a class as an object of research. Then be given preferential treatment in the form of pre-test (preliminary test) $O_{1}$ and continued with the treatment (study using a module-based STEM), and end of the study given the post-test (final test) $\mathrm{O}_{2}$. In this study only one sample group that serves as the control group (before being given treatment) as well as experimental group (after being given treatment). This design is used to view a comparison of the progress of the students after learning by using learning-based module before the STEM. The data in this study were obtained through a test instrument, in the form of questions addressed to the students. Activity analysis of data from the test of the effectiveness of activities carried out using descriptive qualitative approach. Data for the analysis of the results of research conducted test $\mathrm{N}$-gain.

$$
\mathrm{N} \text {-gain }=\frac{\text { score post test }- \text { score pre-test }}{\text { SMI-score pre }- \text { test }}
$$

Captions: SMI = Maximal Ideal Score

The results of the calculation of $\mathrm{N}$-Gain is then interpreted by the use of the classification as shown in table 1 .

Table 1:-Classification Of N-Gain

\begin{tabular}{|c|c|}
\hline Score gain & Criteria \\
\hline $\mathrm{G}<0.3$ & Low \\
\hline $0.3 \leq \mathrm{g}<0.7$ & Are \\
\hline
\end{tabular}


(Meltzer, 2002)

\section{Results and Discussion:-}

Test the effectiveness of the module-based STEM of one class. The effectiveness of this test is done to find out the value of pre-test post-test with. The average value of pretest and posttest can be seen in table 2 .

Table 2:-The Average Value Of Test Results N-Gain

\begin{tabular}{|c|c|c|c|c|c|}
\hline No. & Aspect & $\begin{array}{c}\text { Average value of the } \\
\text { Pre-test }\end{array}$ & $\begin{array}{c}\text { Average value of } \\
\text { the Post-test }\end{array}$ & $\begin{array}{c}\text { Score } \\
\text { N-Gain }\end{array}$ & N-Gain Category \\
\hline 1. & Cognitive & 32 & 75.9 & 0.63 & Are \\
\hline
\end{tabular}

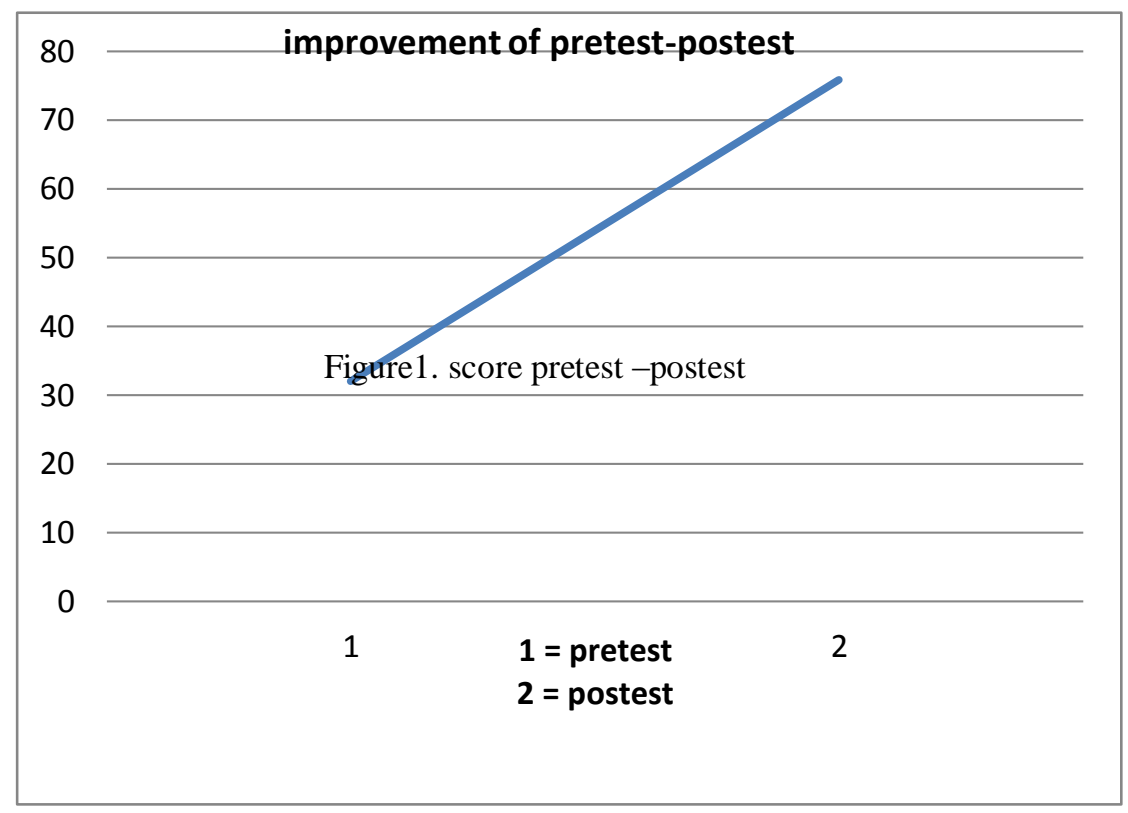

Based on the results of the analysis of data values and known postest pretest that before being given treatment students have not mastered the concept of physics static fluid material. It can be seen from the average value of pretest 32. Student learning outcomes after treatment showed a significant increase. The average value of the posttest students amounted to 75.9. Test results obtained average value post effectiveness test (75.9) average value > pre-test (32). In addition, the average N-Gain (0.63) included in the category of being. Based on the results of the calculation of N-Gain $20.68 \%$ note that students are included in the categories high and $79.31 \%$ students are included in the category of being. The effectiveness of the module is the module's success has been developed with the cognitive domain indicators which include memorizing, understanding, applying, analyzing, evaluating with pretest and post-test to know the increase in student learning outcomes. Learning physics in this study helped with learning materials in the form of the module-based STEM. Learning is performed according to a series of processes that are contained within the module. Students can receive the material properly through discussions, practical work, presentation, and evaluation.

The research results obtained from the study results increases, students enthusiastically followed the learning, this is in line with the opinion (Bibi et al, 2015) whereby the study STEM interest and competence of the students is increasing. A similar study of the STEM can develop when associated with the environment, so as to materialize a study that presents the real world experienced by students in everyday life (Subramaniam et al, 2012). According to research Yuliati et al (2011) some activities such as discussing and making project can improve student learning outcomes. The result is also supported by the results of the study (Roberts,,2012), which reveal the STEM-based learning can add to the learning experience through practice and apply the General principles of the material being studied, so growing creativity, curiosity and encourage cooperation among students. 
The learning associated with aspects of the STEM allows students to understand the concepts of physics combined with technology, engineering, and mathematics through discussions, practical work, and the making of the project, activities - activities that done during the process of learning can interest students and implies an increase in the results of the study. The results of the research of Joseph (2015) stated that learning activities implemented through observation and practice or teaching can improve student learning outcomes.

\section{Conclusion:-}

Based on the results and discussion may be inferred that the module-based STEM (Science, Technology, Engineering, and Mathematics) has been effectively used in the study, the mean value of is seen can post test (75.9)

$>$ value pre-test (32) and the value $\mathrm{N}$-categories include 0.65 gain medium.

\section{Bibliography:-}

1. Becker, K., \& Park, K. 2011. Effects of integrative approaches among science, technology, engineering, and mathematics (STEM) subjects on students learning: A preliminary meta-analysis. Journal of STEM Education: Innovations and Research, 12(5/6), 23.

2. Beers, S. 2011. 21st Century Skills: Preparing Students For Their Future. [Online]http://www.yinghuaaca demy. org/wpcontent/uploads/2014/10/21st_century_skills.pdf), accessed 04 December 2017.

3. Bybee, R. W. 2006. The case for STEM education: Challenges and opportunity. Arlington, VI: National Science Teachers Association (NSTA) Press.

4. Hannover Research. (2015) Project-based Learning and Best Practices for Delivering High School STEM Education.

5. Honey, M., Pearson, G., \& Schweingrube, H. 2014. STEM Integration in K-12 Education: Status, Prospects, and an. Washington DC: National Academy of Sciences.

6. Mayasari, T., Kadarohman, A., \& Rusdiana, D. 2014. The Influence Of Integrated Learning Science, Technology. Engineering, and Mathematics (STEM) On The Results Of Studying Students: Meta-Analysis Study. Pensa Semnas Proceedings VI "The Role Of Science Literacy". 371-377

7. Meltzer. D. E. 2002. The Relationship Between Mathematics Preparation and Conceptual Learning Gains in Physics: A Possible "Hidden Variable" in Diagnostic Pretest Scores. Journal of am J. Phys. 70(12), 160

8. Pfeiffer, H.D, Ignatov, D.I., \& Poelmans, J (2013) Conceptual Structures for STEM Research and Education. 20th International Conference on Conceptual Structures, ICCS 2013 Mumbai, India, January 10-12, 2013Proceedings. Springer. ISBN 978-3-642-35785-5.

9. Prastowo, A. 2013 The Creative Guide Makes Innovative Learning Materials. Yogyakarta: Diva Press.

10. Roberts, A. 2012. A Justification for STEM Education. Technology and Engineering Teacher. 71(8): 1-4. Tersedia di https://www.iteea.org [accessed 19-1-2018].

11. Sanders, M., Hyuksoo. K., Kyungsuk, P. \& Hyonyong, L. 2011. Integrative STEM (Science, Technology, Engineering, and Mathematics) Education: Contemporary Trends and Issues. Secondary Education 59, $729-762$.

12. Subramaniam, M. M., Ahn, J., Fleischmann, K. R., \& Druin, A. 2012. Reimagining the role of school libraries in STEM education: Creating hybrid spaces for exploration. The Library Quarterly, 82(2), 161-182.

13. Sudjana, Nana. 1990. Assessment of the results of the teaching and learning Process. Bandung: Teen Rosdakarya.Suprawoto, N.A.2009. Develop learning materials with Menyususn Module (online) (http://www.scribe.com/doc/16554502/akso accessed April 4, 2018)

14. Van den Akker. 1999. Principles and Method of Development Research. London. Dlm. van den Akker, J., Branch, R.M., Gustafson, K., Nieveen, N., \& Plomp, T. (pnyt.)”. Design approaches and tools in education and training. Dordrecht: Kluwer Academic Publisher.

15. Verma, A. K., Dickerson, D., \& McKinney, S. (2011). Engaging Students in STEM Careers with Project-Based Learning-MarineTech Project. Technology and engineering teacher.

16. White, D.W. 2010. What Is STEM Education and Why Is It Important? Florida Association of Teacher Educators Journal Volume 1 Number 142014 1-9.

17. Yuliati, Di, D. Yulianti, \& S. Khanafiyah. 2011. Physics-based Hands-on Learning Activities to foster critical thinking ability and improving the Learning Outcomes of students of JUNIOR HIGH SCHOOL. The Journal Physics Education Indonesia. 7:23-27. Available at https://journal.unnes.ac.id [accessed 20-5-2018]

18. Yusuf, I. 2015. Improvement of the activity and results of the Study of physics Learning Through Empece on Grade XI-IPA 4 SMA Negeri 5 Lessons 2012/2013 years of Yogyakarta. Scientific Journal Teacher Caraka Olah Educational Thought. 19 (1): 71-78. Available at http://journal.uny.ac.id [accessed 20-5-2018]. 